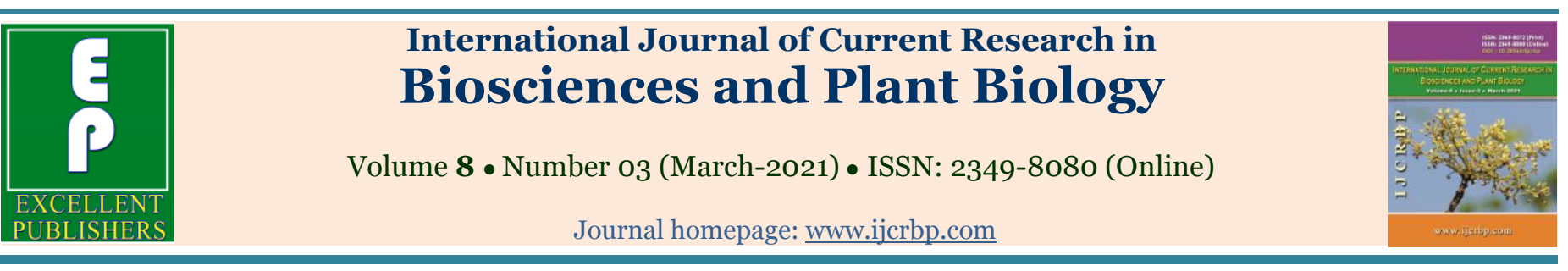

Review Article

doi: $\underline{\text { https://doi.org/10.20546/ijcrbp.2021.803.003 }}$

\title{
Germination, growth, yield and yield component of faba bean (Vicia faba L.) as influenced by seed size and sowing depth: A review
}

\author{
Endalkachew Baye
}

Department of Plant Sciences, Salale University, P.O Box 245, Fitch, Ethiopia

*Corresponding author; e-mail: bayeendalkachew4@gmail.com

\begin{tabular}{ll}
\hline Article Info & Abstract \\
\hline Keywords: & Faba bean (Vicia faba L.) is among the oldest crops in the world. Globally, it is third most important \\
Faba bean & feed grain legume. Currently, 58 countries produce this bean on large scale. Probably faba beans are \\
Germination & one of the best performing crops under global warming and climate change scenario because of its \\
Growth & unique ability to excel under all most all type of climatic conditions coupled with its wide adoptability \\
Seed-size & to range of soil environment. It is a good source of lysine rich protein and good source of levadopa (L- \\
Sowing-depth & $\begin{array}{l}\text { dopa), a precursor of dopamine, can be potentially used as medicine for the treatment of Parkinson's } \\
\text { disease. However, its production is very low due to a number of biotic and abiotic factors. Different } \\
\text { agronomic practices also have an effect on germination, growth, yield and yield components of faba } \\
\text { bean. Thus, the main objective of this seminar is to review the effect of seed size and sowing depth on } \\
\text { faba bean production. }\end{array}$
\end{tabular}

- Received: 18 December 2020 • Revised: 06 February 2021 • Accepted: 14 February 2021 • Published Online: 6 March 2021

\section{Introduction}

Faba bean (Vicia faba L., 2n = 12), is an annual legume that belongs to the family of Fabaceae. (Hanelt and Mettin, 2009). The crop is known by many names, most of which refer to a particular subgroup rather than the whole species (Hawtin and Hebblethpiait, 1983). Faba bean, Fava bean, Broad bean, Horse bean, Windsor bean, Tick beans (small types), Bakela (Ethiopia), Boby kurmouvje (former USSR), Faveira (Portugal), Ful masri (Sudan), Feve (French) and Yeshil Bakla (Turkey) are the few names used in different parts of world (Naqvi, 1984; Singh et $a l ., 2010)$. Field beans are plants which are widely used all around the world. It is the third most important leguminous plant after soybeans (Glycine max L.) and peas (Pisum sativum L.) (Singh et al., 2013). It is assigned to the Central Asian, Mediterranean and South American centers of diversity and believed to be a native to North Africa and southwest Asia, and extensively cultivated elsewhere. Cubero (2003) postulated a Near Eastern center of origin, with four radii to Europe along the North African coast to Spain, along the Nile to Ethiopia, and from Mesopotamia to India. Secondary centers of diversity are postulated in Afghanistan and Ethiopia. However, Hajjar and Hodgkin (2007) reported the origin to be Central Asia.

Faba bean is now grown worldwide. Presently, faba beans are major crop in many countries including 
China, Ethiopia and Egypt, and are widely grown for human food throughout the Mediterranean region and in parts of Latin America (Naqvi, 1984). According to FAO-stat data world average of faba bean productivity in 2017 was $1.5 \mathrm{t} / \mathrm{ha}$ and African average productivity was 1.3 t/ha, Egypt ranked first with 2.96 t/ha (FAO, 2017). Ethiopia was the second largest faba bean producer in the world next to China and accounts for about $12 \%$ of the world area and production with an average yield of $1.1 \mathrm{t} \mathrm{ha}^{-1}$ (CSA, 2018).

Faba beans are major crop in many countries including China, Ethiopia and Egypt, and are widely grown for human food throughout the Mediterranean region and in parts of Latin America (Naqvi, 1984). It serves as daily food and cash crop in many parts of the country (Hawtin and Hebblewate, 1993). This legume crop is also known for its ability to form endosymbiotic association with root modulating Bactria (rhizobia) group called Rhizobium legumin Sarum by faba bean. It is also used as a human food in developing country and as animal food, mainly for pigs, horses, poultry and pigeons in industrialized countries. It is a common breakfast food in the Middle East, Mediterranean region, china and Ethiopia (Bond et al., 1985). This crop sometimes grown for green manure, and livestock feed. It is considered as cash crop. The straw can also use for brick making (Duke, 1981; Bond et al., 1985). It also plays a great role as cash crop, important sources of dietary protein and they correct important amino acid deficiencies and also it improves soil fertility (Abraham, 2008). Faba bean is an important pulse crop grown in the highlands (1800-3000 m.a.s.l.) of Ethiopia, where the soil and weather are considered to be congenial for better growth of the crop.

Faba bean has a great potential to be used as a source of nutrition for human feed, and as a $\mathrm{N}_{2}$ - fixing, legume can also play an essential role in enhancing soil fertility (El-Kholy et al., 2019). With this the crop has been cultivated almost in 58 countries of the world (FAO, 2009). Despite good coverage of the crop, very limited work has been done on its agronomic management and varietals improvement. Constraints that contribute to low productivity of faba bean include improper cultural practices and lack of good quality seeds leading to sub optimum plant stand resulting in poor yield (Singh et al., 2009, Singh et al., 2013). There are a number of cultural practices/agronomic practice that can affect the production and productivity of faba bean in the world. Some of this practice includes sowing depth, planting density, seed size, fertilizer application and time of sowing among others.

Planting depth is critical, since the hard, dry seed takes longer to absorb water and germinate than those common beans (Singh et al., 2013). It is important to plant accurately in order to achieve good germination, emergence and high plant population (Srivastava et al., 2006). The depth of sowing is important in maximizing the potential of seedling emergence and crop yield. Too shallow sowing results in thin germination due to inadequate soil moisture at the top soil layer. On the other hand, deep sowing (e.g. beyond $6 \mathrm{~cm}$ ) can significantly affect crop emergence and yield (Aikins et al., 2006; Mahdi et al., 1998). Many paddock situations can soon suffer a 5-10\% yield loss as a result of poor seeding depth, with more extreme situations suggesting possible yield penalties as high as $15-20 \%$, or more (Desbiolles, 2002). The main objective of seeding is to put seeds at a desired depth and spacing within the row. Uniform depth result in better germination and emergence and increase yield by minimizing competition between plants for available light, water, and nutrients (Karayel and Özmerzi, 2008).

Seed size is an important component in plant fitness. Seed size is an important physical indicator of seed quality that affects the emergence, plant growth and performance of the crop in the field (Adebisi et al., 2013). Indeed, the sowing of mixed seeds of a species may result in a non-uniform stand establishment, what may lead to heterogeneity in the plant vigor and size (Mishra et al., 2010). It is thought commonly to be an important focus of selection on the life histories of plants (Janzen, 1977), because the likelihood of dispersal (Howe and Kerckhove, 1980), germination (Putievsky, 1980) and survival (Schaal, 1980) can all depend on seed size. It is one of the most important characteristics of seeds that can affect seed development and has a special role in crop production. Grading of seed based upon their size and weights is a common practice in a majority of crops as it has been found to regulate the germination and subsequent seedling growth in many plants (Siddig et al., 2015). The size of sown seeds has an effect first on the rate of germination, then the percentage of germination, establishment, seedling vigor and finally the overall performance of different crop plants as reported by different researchers. For example, Leishman et al. (200) stated that seed size affects vigor, germination and seedling establishment. They also reported that small seeds gave 
higher growth parameters like number of leaves per plant, leaf area, root length and plant height. Seedling depth and seed size are the major factors influencing seedling emergence, stand establishment, and crop performance as reported by Lamb and Johnson (2004).

Faba bean is one of the most important food crops in the world particularly in developing countries like Ethiopia. As a result, a number of researches which focuses on agronomic features of faba bean have been conducted by researchers who are found in different countries of the world. However, there is a wide gap in review and documentation of works done on factors that affect the production and productivity of faba bean like seed size, sowing depth, planting density, sowing time, etc. Therefore, it is necessary to compile the already done works so far for easy access by users. Thus, the objective of this work is to review the effect of sowing depth and seed size on germination, growth, yield and yield component of faba bean.

\section{Production of faba bean in the world}

Faba bean (Vicia faba L.) is a much-valued food legume in the Middle-East, the Mediterranean region, China and Ethiopia (Muehlbauer and Tullu, 1997). It is originated from the Middle East in the prehistoric period. Seeds dated from $6250 \mathrm{BCE}$ have been found in Jericho (McVicar et al., 2013). Now faba bean is widespread in Europe, North Africa, Central Asia, China, South America, the USA, Canada and Australia in 2012.

Faba production for food and feed was 4.5 million ton worldwide. The top 5 producing countries of faba bean are China, Ethiopia, and Australia, France and United Kingdom and account for more than $75 \%$ of world production. According to FAO report China alone produced $34 \%$ of all faba beans in 2013(FAO, 2014). However, its utilization and production has been declining in the last decades by $50 \%$ between 1960 to 2010 due to the replacement of traditional cropping systems by industrialized cereal-based systems (Jensen et al., 2010; McVicar et al., 2013).

\section{Economic importance of faba bean}

Field beans are mainly grown for seed production, which are used not only for animal feed but also for food. It is also grown for green forage because it has high nutritional value and crude protein content, but it is not the main reason for field beans growing. In addition, field beans are very suitable for crop rotation, because they improve soil fertility and leave good effect on after crops (Sahile et al., 2008). Due to the growing demand for crop products including crude protein sources and increasing pressure on economic and environmental requirements in agro-ecosystems, legumes also field beans could play a major role in the crop production system (Stagnari et al., 2017).

Faba bean (locally known as Kalimotor or Bakala) seed is used as human food in developing countries and as animal feed in industrialized countries. It can also be used as a vegetable, green or dried, fresh or canned. It is a common breakfast food in the Middle East, Mediterranean region, China and Ethiopia (Bond et al., 1985). Feeding value of faba bean is high, and is considered in some areas to be superior to field peas or other legumes. Sometimes it is grown for green manure. Large-seeded cultivars can be used as vegetable (Duke, 1981). Murinda and Saxena (1985) reported that faba bean fixe more nitrogen $\left(135 \mathrm{~kg} \mathrm{~N} \mathrm{ha}^{-1}\right)$ than lentil and chickpea.

\section{Ecological requirements of faba bean}

Faba bean requires a cool season for best development. It tolerates nearly any soil type and grows best on rich loam soil. It is more tolerant to acid soil conditions than most legumes. Mahler et al. (1988) reported that in terms of nutrient availability best in $\mathrm{pH}$ values between 5.7 and 7.2 when pulse crops are grown on soils whose $\mathrm{pH}$ values are less than 5.6, they give low yields. It is considered to be the least drought resistant of legume crops. However, cultivars with higher water use efficiency have been developed (Bhattacharjee and Dey, 2014). Moisture requirement is high at about 9-12 weeks after establishment. In the tropics and subtropics, faba bean can be grown above $1200 \mathrm{~m}$ and up to an altitude of $2500 \mathrm{~m}$ (Eco crop, 2014). The crop is mainly cultivated in the mid and high-altitude areas characterized with elevation of $1800-2250$ and 22503000 meters above sea level respectively (Mussa and Gamechu, 2006).

Growing season should have little or no excessive heat and optimum temperature for production ranges from 18 to $27^{\circ} \mathrm{C}$ (Duke, 1981). Evenly distributed annual rainfall of $650-1000 \mathrm{~mm}$ is ideal (Kay, 1979). The maturity period ranges from 90.220 days depending up on cultivars and climatic condition (Bond et al., 1985). 


\section{Effect of seed size and sowing depth on faba bean production}

\section{Effect of seed size and sowing depth on faba bean germination}

Seed germination is basic prerequisite for uniform and optimum plant stand per unit area. This is much more of significant, particularly for slow starter, faba bean is one of the slowest germinators, taking time 7-15 days (Singh et al., 2013). On another work Siddig et al. (2015) reported that first seed germination emerged 8 days after sowing and continued 8-14 days, days taken to initiate and complete the germination of seeds varied in different seed sizes. Faba bean requires a cool season for best development. It is grown as a winter annual in warm temperate and subtropical areas. Germination is first step toward the activation of life cycle, which takes place under favorable agroclimatic conditions. Time taken by plant to germinate is governed by depth of seeding, size of seed (reserve food material). Successful germination is based on size of seed (reserve food material) and length of plumose and coleoptiles of particular crops.

The time required by the faba bean seed is dependent both the size and sowing depth (Singh et al., 2010). According to Singh et al. (2012) each increase in depth of seeding delayed the germination by time taking more time to emerge. Medium depth of sowing takes (8.5day) significantly more (7.8 days) and less (9.5 days) time than shallow and deep depth of sowing respectively. Aikins et al. (2006) also indicated that the number of germinated seeds was greatly reduced with the increased depth of planting, too shallow sowing results in poor germination due to inadequate soil moisture at the top soil layer, deep sowing can also significantly reduce crop emergence and yield. Nabi et al. (2011) also reported the negative effect of deep sowing depth, who found that seedling emergence, was decreased with increased sowing depth in cotton. The deeper the seed is sown the more strength it needs to push its shoots above the soil surface.

Similarly, Umeoka and Ogbonnaya (2016) stated that telfairia seeds sown at $3 \mathrm{~cm}$ and $6 \mathrm{~cm}$ depths germinated faster than seeds sown at $9 \mathrm{~cm}$ and $12 \mathrm{~cm}$ depths. Seeds sown at $3 \mathrm{~cm}$ depths had the highest significant percentage germination. The earliness in germination and the establishment of germinated seedlings on the ground of small seeds over larger and medium seeds is also reported in different wheat cultivars and rice by Lafond and Baker (1986) and Roy et al. (1996) respectively. These researchers stated that large seeds have slower germination rates than small seeds. The depth of sowing also has an effect on other phenological parameters like days to first flowering and days to maturity of faba bean (Singh et al., 2013). According to these researchers both parameters have better value at shallow depth and for every increase in sowing depth there is increase in both parameters. According to Singh et al. (2010) with the small, increasing in depth of seeding the days to onset of first flowering prolonged. Shallow depth of seeding, takes significantly minimum time (59.3 days) first flowering higher depth of seeding.

NDSU (2008) also reported that the ability of the germinating soybean seedling to push through a crusted soil decreases with deeper planting; and percent emergence decreased with increasing planting depth. These emergences of soybean seedlings decrease markedly if seeds are sown deeper than $5 \mathrm{~cm}$. In contradiction to this Brown et al. (2003) reported the positive effect of deep sowing and stated that deeper sowing also reduces the number of seeds removed by birds and mice.

The time taken by the seed may also vary with the size of the seed sown. Boldness of seed had direct and positive bearing on early emergence. Extra bold seed size class taken minimum duration to germinate (7.2 days) whereas maximum was taken by small seeded group (10.5 days). Medium size seed class (M) took (8.7 days) significantly minimum and maximum time to $50 \%$ germination over small seeded group (10.5 days) and bold (8.0 days) and extra bold seed size class (7.2 days) respectively (Singh et al., 2010). Because, different size of seeds having different levels of starch and other food storage may be one factor that influences the expression of number of germinated seeds in faba bean (Siddig et al., 2015). Similarly, Hojjat (2011) reported that the germination parameters were significantly related by seed weight and large seed germinated early and showed better germination than small seeds of lentil genotypes. However, Gan et al. (2003) reported that using small seeds can reduce the production cost of chick pea by 15 to $20 \%$ by reducing the amount of seed needed per unit area. In another research Steiner et al. (2019) reported the earliness of small seeds over large seeds in peanut and suggest that the germination process of large seeds was delayed, when compared to small and medium seeds. This delay 
occurred because large seeds need more water absorption than small seeds and, consequently, they take more time to germinate. Shahi et al. (2015) also reported that the germination speed index of wheat large size seeds is lower than those of the small and medium size seeds. The effect of both sowing depth and seed size on germination rate of seeds is also reported in another crop called telfairia by Umeoka and Ogbonnaya (2016). They reported that small and large seeds had significantly the highest and least germination rates respectively. However, a contradictory result was reported Saeed and Shaukat (2000) for seed size and germination in Senna occidentalis Link. The researchers reported that seed size/weight in Senna occidentals exhibited a significant effect on seed germination and emergence percentage with large seeds showing greater germination as well as emergence percentages.

Indira et al. (2000) also reported that seed size is a considerable and significant factor in the germination and early stage of plant growth. The non-significance effect of seed size on seed germination was reported from common bean by Lima et al. (2005) who found that seed germination was not affected by seed size with in different cultivars of faba bean. Shipley and Parent (1991) also found that seed germination percentage was not affected by seed size. Singh et al. (2013) also reported the non- significance of seed size on germination of 6 cultivars of common beans. On another research Singh et al. (2010) reported the occurrence of early and first flowering from faba bean plants raised from extra bold seeds over bold and small seeds.

The interaction between two factors was also recorded for days taken to fifty per cent germination. Small seeded seed size class took significantly minimum time (9.5 days) to germinate when sown at shallow depth over deep sowing (11.5 days). Quickest and slowest to complete 50 per cent germination by extra bold seeded group sown at shallow depth (6.5 days) and small seeded class $(\mathrm{S})$ sown at maximum depth $(12 \mathrm{~cm})$ to the extent of 11.5 days (Singh et al., 2012). The interaction effect of sowing depth and seed size is also reported in cashew by Akos et al. (2017). Umeoka and Ogbonnaya (2016) also reported the interaction effect of seed size and sowing depth on germination and emergence. They found that small seeds sown at deeper depth (9 and 12 $\mathrm{cm})$ germinated faster when compared with shallow depth (3 and $6 \mathrm{~cm})$. Aikins et al. (2006) also stated that interaction between seed size and depth of planting greatly reduced the number of germinated seeds with increased depth of planting, deep sowing can also significantly reduce crop emergence and yield. However, Siddig et al. (2015) reported contradictory result to both sowing depth and seed and stated that the effects of seed size and sowing depth on number of germinated seeds were not significantly different. Another negative effect of sowing depth also reported by Mahdi et al. (1998) and Schillinger et al. (1998) who stated that increasing sowing depths can enhance wheat establishment because of the higher soil-water content in the seed zone, resulting in better germination and emergence of seedlings.

\section{Effect of seed size and sowing depth on faba bean growth}

An important objective of seeding for improved crop performance is putting seeds at a desired depth. Seeds should be sown at a depth that increases the likelihood of germination, emergence and improved growth. The depth of sowing is important in maximizing not only germination and its related parameters but also the potential of plant height and other growth-related characteristics of plants (Aikins et al., 2011). Height of fava bean plant is largely governed by its genetic makeup and their growing environment. Fava bean employs a high degree of plasticity (Hodgson and Blackman, 1956). Shallow depth of seeding at $\left(D_{1}\right)$ recorded significantly taller plant compared to deep seeding $\left(D_{3}\right)$ (Singh et al., 2010). In their experiment they also recorded the highest number of reproductive branches per plant at lower sowing depth than deeper depth. Siddig et al. (2015) reported that the length of a seedling in centimeter and number of leaves per plant decreased from 22.4 to $21.8 \mathrm{~cm}$ and 11.2 to 10.4 respectively as the sowing depth of faba bean seeds increased from $5 \mathrm{~cm}$ to $10 \mathrm{~cm}$.

Aikins et al. (2011) also reported the decrease in plant height and number of leaves per plant with an increase in sowing depth of soybean. They recorded the tallest plant height and the highest number of leaves per plant in soybean from seeds sown at a depth of $5 \mathrm{~cm}$ and the value decreased as the depth of sowing increases to 9 $\mathrm{cm}$. They also reported the negative interaction of increase in sowing depth with stem girth in soybean and found that the stem girth obtained from seeds sown at a shallow depth $(3$ and $5 \mathrm{~cm}$ ) is greater than that of plants raised from sees sown at deeper depth $(08$ and $9 \mathrm{~cm})$. The effect of sowing depth on growth parameters is also 
reported in another crop called telfairia by Umeoka and Ogbonnaya (2016). Seeds sown at shallow depth $(3 \mathrm{~cm})$ depths had the highest significant plant heights, root shoot ratio and leaf area than seeds sown at deeper depth $(9$ and $12 \mathrm{~cm}$ ). The negative effect of sowing depth on seedling height after $12 \mathrm{~cm}$ in Cashew is also reported by Akos et al. (2017). The higher height of seedlings was reported from shallow depth of sowing.

The size of seeds sown also have its own effect on plant height, number of reproductive branches per plant and number of leaves per plant of faba bean plant. According to Singh et al. (2010), both plant height and number of reproductive branches per plant was higher small seed size and stated that both growth parameters decreased with an increase in seed size In another research Kondra (1975) found that Medium seed size class produced tallest plant, significantly superior over small (S) and extra bold (EB), whereas smallest plant was recorded in small seed size class. The effect of both sowing depth and seed size on growth parameters of plants is also reported in another crop called telfairia by Umeoka and Ogbonnaya (2016). Small seeds gave significantly the highest leaf number per plant, leaf area, root length, relative growth rate and leaf, stem and root dry weights. In their work large seeds had statistically the least result of the above parameters.

Dhillon and Kler (1976) also noted that plants established from small-seeds soybean varieties yielded more leaves and shoots than those established from large-seeded varieties. However, Siddig et al. (2015) reported the increase growth parameters of faba bean like seedling length, number of leaves per plant, with an increase in seed size of faba bean. Other contradictory idea is also reported from Senna occidentalis Link by Saeed and Shaukat (2000). The found that small seed category showed lesser seedling growth while large seeds showed greater seedling growth i.e., root and shoot growth of seedlings was greater in case of large seeds. Similarly, Mian and Nafziger (1994) reported a direct relationship of seed size with seedling shoot and root weight. Seedling root and shoot length for big bluestem also have been shown to be positively correlated with seed size (Springer, 1991). The increase in growth parameters of plants with an increase in seed size is also reported by Lima et al. (2005) particularly for common bean cultivars.

The significant interaction among the treatment combination (seeding depth and seed size class) also have an effect on growth parameters of faba bean. The highest plant height $(88.7 \mathrm{~cm})$ was noticed when medium size seed class was sown at shallow depth, whereas minimum $(79.4 \mathrm{~cm})$ was noticed in case of small seed class and deeper depth of seeding. Shallow depth and medium seed class combination produced tallest plant $(88.7 \mathrm{~cm})$ than small seed class sown at any depth of sowing and extra bold seed class (EB) sown at $8 \mathrm{~cm}$ and $12 \mathrm{~cm}$ depth (Singh et al., 2012). They also reported the decrease in the number of reproductive branches per plant with an increase in sowing depth.

\section{Effect of seed size and sowing depth on faba bean yield and yield component}

The production and productivity of crop plants is dependent on the performance of that crop at different stages of its growth. Yield and yield components have their own share on overall production and productivity. Intern the response of yield and yield components can be affected by a number of factors. Among the many factor's selection of appropriate agronomic practices (Seed size and sowing depth) play a significant role. According to Singh et al. (2013) sowing depth have an effect on a number of yield and yield components of faba bean like number of pods per plant, pod length in $\mathrm{cm}$, number of seeds per pod, seed yield per plant in gram, seed yield in kg per hectare and 100 seeds weight (g). Based on the result of these researchers' number of pods per plant, pod length (in $\mathrm{cm}$ ) and 100 seeds weight (in g) were higher at shallow depth of sowing $(5 \mathrm{~cm}$ ) compared with higher depth of sowing (10) and the values decreased as the sowing depth increased. However, the remaining yield related parameters (grains per pod, seed yield per plant and seed yield per hectare) have better value at moderate sowing depth.

Singh et al. (2010) found the significance effect of sowing depth on number of pods per plant and pod length in $\mathrm{cm}$ in faba bean. The higher number of pods per plant (54.2) and the tallest pod length $(4.36 \mathrm{~cm})$ were found at shallow sowing depth and the values decreased with an increase in seeding depth. According to Singh et al. (2012) the sowing depth have a significance effect on a number of yield and yield component of faba bean like number of grains per pod, number of pods per plant, pod length in $\mathrm{cm}$, seed yield (g/plant), 100 seeds weight and yield in $\mathrm{kg} / \mathrm{ha}$. The higher value of all these parameters were found from seeds sown at shallow depth and the values decreased as the depth of sowing increased. The significance 
difference in yield and yield components of wheat with respect to sowing depth is also reported by Yagmur and Kaydan (2009). Similarly, the number of pods per plant and grain decreased with increasing plant depth soybean as reported by Lawson et al. (2008). In contrary with the report of Singh et al. (2013), Singh et al. (2010) found that with the increase in depth of sowing the number of grains per pod, seeds per plant and seed yield per hector decreased.

Seed size class had also exerted significant impact on number of pods per plant. Number of pod per plant is by and largely governed by its (fava bean) genetic makeup and up to considerable extent. by management practices. Each seed size class is unique and distant from each other. According to Singh et al. (2010) maximum number of pods per plant (52.7) was recorded with small (S) seed size class whereas minimum (33.5) was obtained with extra bold (EB) seed size class. Similarly, Singh et al. (2012) reported a significance effect of seed size on a number of yield and yield component of faba bean like number of grains per pod, number of pods per plant, pod length in $\mathrm{cm}$, seed yield (g/plant), 100 seed weight and yield in $\mathrm{kg} / \mathrm{ha}$. These, researchers found that small seed classes gave the highest value of all the parameters.

According to Singh et al. (2012) the interaction of both sowing depth and seed size have a significance effect on a number of yield and yield component of faba bean like number of grains per pod, number of pods per plant, pod length in $\mathrm{cm}$, seed yield (g/plant), 100 seed weight and yield in $\mathrm{kg} / \mathrm{ha}$. The interaction effect of both factor (sowing depth and seed size class) showed a significance difference number of pods per plant and pod length in $\mathrm{cm}$ in faba bean as reported by Singh et al. (2010). They recorded maximum number of pods per plant (54.2) and $4.32 \mathrm{~cm}$ long pod recorded from small seed size class planted at shallow depth of planting. They also stated the value of both parameters decreased as the two factors increased simultaneously. However, the interaction effect of sowing depth and seed size is not significant on a number of yield attributes like number of grains per pod, seeds per plant and seed yield per hector.

\section{Conclusions}

Faba bean is one of the widely cultivating food crops in the world that can supply a number of nutritionally important nutrients for the ever-increasing world population. Even though faba bean is called as poor man's meat with its higher protein content its production in the world is not equivalent to its area of coverage due to a number of biotic and abiotic factors. Among the many constraints of faba bean production improper cultural practices (sowing depth, planting density or spacing, seed size, time of sowing or planting), lack of good quality and improved seeds that can lead to sub optimum plant stand and poor yield are some to mention. Naturally variation in seed size has been observed in many crop species among populations, among plants within populations and within single plants including faba bean. The variation seed size has its own effect on the overall production and productivity of faba bean. Additionally, seed size has a strong correlation or interaction with sowing depth of a certain crop plant. Therefore, it is important to select the appropriate seed size and plant accurately in order to achieve good germination, emergence and high plant population. Both seed size and depth of sowing are important in maximizing the potential of seedling emergence and crop yield. Too shallow sowing results in thin germination due to inadequate soil moisture at the top soil layer. On the other hand, deep sowing (e.g. beyond $6 \mathrm{~cm}$ ) can significantly affect crop emergence and yield. However, this response can vary with variation in seed size and environmental condition. With respect to fava bean different individuals have reported different ideas regarding the effect of seed size and sowing depth on germination, growth and yield of faba bean.

Generally, it can be concluded that seeds sown at shallow depth have responded well almost in all phenological, growth, yield and yield component of faba bean. However, the effect of genotype on the different growth stage of faba bean needs attention.

\section{Conflict of interest statement}

Author declares that there is no conflict of interest.

\section{References}

Abraham, T., 2008. Increasing Crop Production through Improved Plant Production. Vol. I. Addis Ababa, Ethiopia.

Adebisi, M. A., Kehinde, T. O., Salau, A. W., Okesola, L. A., Porbeni, J. B. O., Esuruoso, A. O., Oyekale, K. O., 2013. Influence of different seed size fractions on seed germination, seedling emergence 
and seed yield characters in tropical soybean (Glycine $\max$ L. Merrill). Int. J. Agric. Res., 8(1): 26-33.

Agricultural Research in Dry Areas. Addis Ababa, Ethiopia, 3-19 pp. Eco crop, 2014. Eco crop data base. FAO, Rome, Italy.

Aikins, S.H.M., Afuakwa, J.J., Baidoo, D., 2006. Effect of planting septh on maize stand establishment. J. Ghana Inst. Engineers, 4(2): 20-25.

Aikins, S.H.M., Afuakwa, J.J., Nkansah, E.O., 2011. Effect of different sowing depths on soybean growth and dry matter yield. Agric. Biol. J. N. Am., 2(9): 1273-1278.

Akos, I.S., Tagwai, M.Y., Dabo, J., 2017. Effect of interaction between seed size and sowing depth of cashew Anacardium occidentale (L.) on seedlings emergence and height under treatment with organic and inorganic fertilizer in Gidan-Waya, Southern Guinea Savanna. Nig. Sci. World J., 12(2): 28-35.

Alka, M., Swamy, S.L., Bargali, S.S., Singh, A.K., 2010. Tree growth, biomass and productivity of wheat under five promising clones of Populus deltoides in agrisilviculture system. Int. J. Ecol. Environ. Sci., 36: 167-174.

Bhattacharjee, R., Dey, U., 2014. Biofertilizer, a way towards organic agriculture: A review. Afr. J. Microbiol. Res., 8: 2332-2343.

Bond, D.A., Lawes, D.A., Hawtin, G.C., Saxena, M.C., Stephens, J.S., 1985. Faba bean (Vicia faba L.). p. 199-265. In: Summerfield, R.J., Roberts, E.H. (Eds.), Grain Legume Crops. William Collins Sons Co. Ltd., 8 Grafton Street, London, WIX 3LA, UK.

Brown, P.R., Singleton, G.R., Tann, C.R., Mock, I., 2003. Increasing sowing depth to reduce mouse damage to winter crops. Crop Prot., 22: 653-660.

Central Statistical Agency (CSA), 2018. Agricultural sample survey. Report on Area and Production for Major Crops (Private Peasant Holdings, Meher Season). Addis Ababa, Ethiopia.

Cubero, J.I., 1974. On the evolution of Vicia faba. Theor. Appl. Genet., 45: 47-51.

Desbiolles, J., 2002. Optimizing seeding depth in the paddock. Available Oline: http://www.unisa.edu.au /amrdc/Areas/Proj/SeedTrials/seeding_depth_article _Kerribee.pdf

Dhillon, G. S., Kler, D. S., 1976. Crop production in relation to seed size. Seed Res., 4: 143-155.

Duke, J.A., 1981. Handbook of Legumes of World Economic Importance. Plenum Press, New York. pp.199-265.

El-Kholy, A.S.M., Aly, R.M.A., El-Bana, A.Y.A.,
Yasin, M.A.T., 2019. Yield of faba bean (Vicia $f a b a$, L.) as influenced by planting density, humic acid rate and phosphorus fertilization level under drip irrigation system in sandy soils. Zagazig J. Agric. Res., 4(6A): 1785-1795.

FAO (Food and Agricultural Organization of the United Nations), 2017. Statistical Pocket Book for World Food and Agriculture. Rome, Italy.

FAO STAT, 2009. Production Stat: Crops. FAO statistical databases (FAO Stat), Food and Agriculture Organization of the United Nations (FAO), http://faostat.fao.org.

FAO, 2014. Production Stat: Crops. FAO statistical databases (FAO Stat), Food and Agriculture Organization of the United Nations (FAO), http://faostat.fao.org.

Hajjar, R, Hodgkin, T., 2007. The use of wild relatives in crop improvement: a survey of developments over the last 20 years. Euphytica, 156: 1-13.

Hanelt, P., Mettin, D., 1989. Biosystematics of the genus Vicia L. (Leguminosae). Annu. Rev. Ecol. Syst., 20: 199-223.

Hawtin, G.C., Hebblethpiait, P.D., 1983. Background and history of faba bean production. In: Hebblethwaite, P.D. (Ed.) The Faba Bean (Vicia faba L.). Buttenvorths, London, U.K. pp.3-22.

Hodgson, G. L., Blackman, G. E., 1956. Analysis of the influence of plant density on the growth of Vicia faba L.: The influence of density on the pattern of development. J. Exp. Bot., 7: 141-165.

Hojjat, S.S., 2011. Effect of seed size on germination and seedling growth of some lentil genotypes. Int. J. Agric. Crop Sci., 3: 1-5.

Howe, H.F., Kerckhove, G.A.V., 1980. Nutmeg dispersal by tropical birds. Science, 210: 925-927.

Indira, E.P., Chand, B.S., Chacko, K.C., 2000. Effect of seed size grading on germination and growth of teak (Tectona grandis) seedlings. J. Trop. For. Sci., 12(1): 21-27.

Janzen, D.H., 1977. Promising directions of study in tropical animal-plant interactions. Ann. Missouri Bot. Garden, 64: 706-736.

Jensen, E., Peoples, M., Hauggaard-Nielsen, H., 2010. Faba bean in cropping Systems. Field Crops Res., 115: 203-216.

Karayel, D., Özmerzi, A., 2008. Evaluation of three depth control components on seed placement accuracy and emergence for a precision planter. Appl. Eng. Agric., 24(3): 271-276.

Kondra, Z. P., 1975. Effects of effects of row spacing, seeding rate and date of seeding of fava beans. Can. 
J. Plant Sci., 55: 211-214.

Lafond, G. P., Baker, R. J., 1986. Effects of temperature, moisture stress, and seed size on germination of nine spring wheat cultivars. Crop Sci., 26: 563-567.

Lamb, K. E., Johnson, B. L., 2004. Seed size and seedling depth influence on canola emergence and performance in the Northern Great Plains. Agron. J., 96: 454-461.

Lawson, I. Y. D., Mensah, E. A., Yeboah, E. N., 2008. Improving the establishment and yield of soybean through planting depth and land preparation methods in Northern Ghana. West Afr. J. Appl. Ecol., 14: 1-8.

Leishman, M. R., Wright, I. J., Moles, A. T., Westoby, M., 2000. Evolutionary ecology of seed size. In: Fenner , M. (Ed.). Seeds. The Ecology and Regeneration in Plant Communities. 2nd Edn. CAB Int., New York. pp.31-57.

Lima, R. E., Santiago, A. S., Araujo, A.P., Teixeira, M.G., 2005. Effects of the size of sown seed on growth and yield of common bean cultivars of different seed size. Braz. J. Plant Physiol., 17(3): 273-281.

Mahdi, L., Bell, C.J., Ryan, J., 1998. Establishment and yield of wheat (Triticum turgidum L.) after early sowing at various depths in a semiarid Mediterranean environ. Field Crops Res., 58: 187196.

Mahdi, L., Bell, C.J., Ryan, J., 1998. Establishment and yield of wheat (Triticum turgidum L.) after early sowing at various depths in a semi-arid Mediterranean environment, Field Crops Res., 58: 187-196.

McVicar, R., Panchuk, D., Brenzil, C., Hartley, S., Pearse, P., Vandenberg, A., 2013. Faba bean. Gov. Saskatchewan, Agriculture, Crops.

Mian, M.A.R., Nafziger, E.D., 1994. Seed size and water potential effects on germination and seedling growth of winter wheat. Crop Sci., 34: 169-171.

Muehlbauer, F., Tullu, A., 1997. Vicia faba L. Purdue Univ., Cent. New Crops Plants Prod., New Crop Factsheet.

Murinda, M.V., Saxena, M. C., 1985. Agronomy of faba beans, lentils and chickpeas. In: Saxena, M.C., Verma, S. (Eds.), Proceedings of the International Workshop on Faba Beans, Kabuli Chickpeas and Lentils in the 1980s. ICARDA, 16-20 May, 1983. Aleppo, Syria. pp. 229-244.

Nabi, G., Mullins, C.E., Montemayor, M.B., Akhtar, M.S., 2001. Germination and emergence of irrigated cotton in Pakistan in relation to sowing depth and physical proprieties of the seedbed. Soil Till. Res., 59: 33-44.

Naqvi, H.K., 1984. Cultivation under the Sultans of Delhi c. 1206-1555. Indian J. History Sci., 19: 329 340.

NDSU, 2008. Soybean planting depth is critical. http//www.ag.udsu.edu/procrop/syb/sybpdc05.htm.

Putievsky, E., 1980. Germination studies with seed of caraway, coriander and dill. Seed Sci. Technol., 8: 245-254.

Roy, S. K. S., Hamid, A., Gia, S. M. M., Hashem, A., 1996. Seed size variation and its effects on germination and seedling vigor in rice. J. Agron. Crop.Sci., 176: 79-82.

Saeed, S., Shaukat, S. S., 2000. Effect of seed size on germination, emergence, growth and seedling survival of Senna occidentals Link. Pak. J. Biol. Sci., 3: 292-295.

Sahile, S., Fininsa, C., Sakhuja, P.K., Ahmed, S., 2008. Effect of mixed cropping and fungicides on chocolate spot (Botrytis fabae) of faba bean (Vicia $f a b a$ ) in Ethiopia. Crop Prot., 27: 275-282.

Schaal, B.A., 1980. Reproductive capacity and seed size in Lupinus texensis. Am. J. Bot., 67: 703-709.

Schillinger, W.F., Donaldson, E., Allan, R.E., Jones, S.S., 1998. Winter wheat seedling emergence from deep sowing depths. Agron. J., 90: 582-586.

Shahi, C., Bargali, K., Bargali, S.S., 2015. How seed size and water stress effect the seed germination and seedling growth in wheat varieties?. Curr. Agric. Res. J., 3(1): 60.

Shipley, B., Parent, M., 1991. Germination responses of 64 wetland species in relation to seed size, minimum time to reproduction and seedling relative growth rate. Funct. Ecol., 5: 111-118.

Siddig, A., Ali, M., Abdellatif Idris, Y., 2015. Effect of seed size and sowing depth on germination and some growth parameters of faba bean (Vicia faba L.). Agric. Biol. Sci. J., 1(1): 1-5.

Singh, A.K., Bhatt, B. P., Sundaram, P.K., Chandra, N., Bharati, R. C., Patel, S. K., 2012. Faba bean (Vicia faba L.) phenology and performance in response to its seed size class and planting depth. Int. J. Agric. Stal. Sci., 8(I): 97-109.

Singh, A.K., Bhatt, B.P., Sundaram, P.K., Gupta, A.K., Singh, D., 2013. Planting geometry to optimize growth and productivity in faba bean (Vicia faba L.) and soil fertility. J. Environ. Biol., 34: 117-122.

Singh, A.K., Chandra, N., Bharati, R.C., Dimree, S.K., 2010. Effect of seed size and seeding depth on fava 
bean (Vicia fava L.) productivity. Environ. Ecol., 28: 1722-1527.

Singh, A.K., Bharati, R.C., Manibhushan, N.C., Pedpati, A., 2013. An assessment of faba bean (Vicia faba L.) current status and future prospect. Afr. J. Agric. Res., 8: 6634-6641.

Singh, A.K., Dimree, S.K., Khan, M.A., Upadhyaya, A., 2009. Agronomic Evaluation of faba bean (Vicia faba L.) performance under impending climate change situation. National Symposium on Recent Global Developments in the Management of Plant Genetic Resources. Indian Society of Plant Genetic Resources, New Delhi, pp.171-179.

Springer, T.L., 1991. Caryopsis size and germination of Andropogon gerardii pedicellate and sessile spikelets. Seed Sci. Technol., 19: 461-468.

Srivastava, A.K., Goering, C.E., Rohrbach, R.P., Buckmaster, D.R., 2006. Engineering Principles of Agricultural Machines. $2^{\text {nd }}$ Edn. American Society of Agricultural and Biological Engineers, Michigan.
Stagnari, F., Maggio, A., Galieni, A., Pisante, M., 2017. Multiple benefits of legumes for agriculture sustainability: an overview. Chem. Biol. Technol. Agric., 4: 1-13.

Steiner, F., Zuffo, A. M., Busch, A., Sousa, T. de O., Zoz, T., 2019. Does seed size affect the germination rate and seedling growth of peanut under salinity and water stress? Pesqui. Agropecu. Trop., 49: e54353.

Umeoka, N., Ogbonnaya, C. I., 2016. Effects of seed size and sowing depth on seed germination and seedling growth of Telfairia occidentalis (Hook F.). Int. J. Adv. Chem. Eng. Biol. Sci., 3(2): 201207.

Yagmur, M., Kaydan, D., 2009. The effects of different sowing depth on grain yield and some grain yield components in wheat (Triticum aestivum L.) cultivars under dryland conditions. Afr. J. Biotechnol., 8: 196-201.

\section{How to cite this article:}

Baye, E., 2021. Germination, growth, yield and yield component of faba bean (Vicia faba L.) as influenced by seed size and sowing depth: A review. Int. J. Curr. Res. Biosci. Plant Biol., 8(3): 15-24.

doi: https://doi.org/10.20546/ijcrbp.2021.803.003 